\title{
Hemophilic Arthropathy in Children: Pathophysiology, Diagnosis and Management
}

\author{
Çocukluk Çağında Hemofilik Artropati: Patofizyoloji, Tanı ve Tedavi
}

\author{
Banu TURHAN ${ }^{1}$ \\ (1) 0000-0001-8474-6835 \\ Yalçın TURHAN ${ }^{2}$ \\ (D) 0000-0002-1440-9566
}

\begin{abstract}
Arthropathy is a serious and common problem in patients with hemophilia impairing the patient's quality of life seriously. The most commonly affected joints in hemophilic arthropathy are knees, ankles and elbows. Even a single bleeding could cause devastating effects to synovium, cartilage and also subchondral bones. Ultrasound and magnetic resonance imaging have been advocated for the studying of cartilage damage. Prophylaxis has been demonstrated as a standard choice of management to prevent hemophilic arthropathy development. Primary prophylaxis starting at early years of age is very important to prevent hemorrhages but secondary prophylaxis in adolescents has also significant success rates. As the duration of exposure to the blood increases in the joint cavity, degeneration of the cartilage matrix and resultant cartilage loss also increase, so the aspiration of the hematoma from joint plays an important role in prevention of the disease progression. Synovectomy may be required in cases where prophylaxis and aspiration does not prevent the recurrent hemorrhages. The purpose of synovectomy either with medical or surgical methods is to remove the problematic synovium to prevent the progression of hemophilic arthropathy. Medical synovectomy (synoviorthesis) has two basic types; radiosynovectomy and chemical synovectomy and the former one is appearing to be more effective with an about $85 \%$ success rates. If all of these measures fail to prevent the progressive cartilage damage, open or arthroscopic synovectomy, arthrodesis of the affected joint or even arthroplasty could be necessary. Here we tried to summarize the pathological mechanism, diagnosis and management of hemophilic arthropathy in children.
\end{abstract}

Keywords: Hemophilia; arthropathy; synovitis; diagnostic imaging.

\section{ÖZ}

Hemofili hastalarında yaygın olarak gözlenen artropati, yaşam kalitesini ciddi biçimde bozan bir problemdir. Hemofilik artropatide en stk etkilenen eklemler dizler, ayak bilekleri ve dirseklerdir. Eklem içinde gözlenen tek bir kanama bile sinovyum, kıkırdak ve subkondral kemikler dâhil eklemin tüm bileşenlerinde yıkıcı bir takım etkilere neden olabilir. Kıkırdak hasarı ve artropatinin erken dönem değişikliklerinin incelenmesi için daha çok ultrason ve manyetik rezonans görüntüleme kullanımı önerilmektedir. Profilaksi, hemofilik artropati gelişimini önlemek için standart bir tedavi seçeneği olarak gösterilmiştir. Erken yaşta başlanan primer profilaksi kanamaların önlenmesi açısından çok önemlidir ancak adölesan dönemde başlanan sekonder profilaksinin de tekrarlayan kanamaların önlenmesi ve kıkırdak hasarının gelişiminin geciktirilmesi konularında sağladığı ciddi faydaları bilinmektedir. Eklemin kanamaya maruz kalma süresi arttıkça, kıkırdak matriksinin dejenerasyonu ve buna bağlı kıkırdak kaybı da artacağı için eklem içindeki hematomun aspirasyonu hastalığın ilerlemesinin önlenmesinde önemli rol oynar. Profilaksi ve aspirasyonun tekrarlayan kanamaları engelleyemediği durumlarda ise hastalara sinovektomi uygulanması gerekebilir. Gerek medikal gerekse cerrahi yöntemlerle yapılabilen sinovektominin amacı sorunlu sinovyumu ortadan kaldırarak hemofilik artropatinin ilerlemesini önlemektir. Tıbbi sinovektomi (sinoviyortez) radyosinovektomi ve kimyasal sinovektomi olarak iki farklı başlık altında incelenebilir. Bunlardan radyosinovektominin yaklaşık \%85 başarı oranı ile kimyasal sinovektomiye göre daha etkili olduğu bildirilmektedir. Tüm bu önlemlerin ilerleyici kıkırdak hasarını önlemede başarısız olduğu durumlarda, açık veya artroskopik sinovektomi, etkilenen eklemin artrodezi ve hatta artroplasti gibi uygulamalara ihtiyaç duyulabilmektedir. Burada, çocukluk çağında gözlenen hemofilik artropatinin patofizyolojisi, teşhis yöntemleri ve tedavisinin güncel literatür eşliğinde tartışılması amaçlanmıştır.

Accepted / Kabul Tarihi : 17.05.2021 Available Online /

Anahtar kelimeler: Hemofili; artropati; sinovit; tanısal görüntüleme. 


\section{INTRODUCTION}

Deficiency of specific coagulation factors like factor VIII (FVIII) and factor IX (FIX) causes hemophilia A and B respectively (1). The diseases are divided into three different degrees of severity according to the remaining defective factor activity level; severe, moderate and mild. Factor activity is less than $1 \%$ in severe, between 1 to $4 \%$ in moderate and between 5 to $40 \%$ in mild cases (2). The responsible genes to synthesize FVIII and FIX are located on the chromosome $\mathrm{X}$. The prevalence of hemophilia is about 1 to 2 per 10.000 men and hemophilia $\mathrm{A}$ is 4 times more common than hemophilia B (3). Although they are well-known pathologies all over the world and there are very effective treatment modalities; if not managed properly since infancy, they could cause some lifelong disabilities (4). One of the most significant and disabling complications of hemophilia is hemophilic arthropathy (HA). In HA, repeated intra-articular bleedings that commonly seen in patients with severe hemophilia are responsible from the pathology and the knees, the elbows and the ankles are affected in most of the times from this complication (5). Different levels of dysfunction caused by HA can affect a person's quality of life severely. In this study it is aimed to elucidate pathophysiology, diagnosis, management modalities of HA in the light of the current literature.

\section{PATHOPHYSIOLOGY}

Recurrent bleeding is one of the major problems in patients with severe hemophilia eventually causing HA. Even a single bleeding could cause some devastating effects to all components of the joint (6). The elbows, the knees, hips and the ankles are the major joints affected by HA (7). Intensive mechanical forces and rich vascularization in these joints could be the cause of this high frequency. Blood clotting is already impaired even in a normal joint space and also local fibrinolysis is increased in hemophilic patients (8). The risk of recurrent bleedings increases with the formation of new and brittle vessels along with the synovial thickening after first hemorrhage. The pathophysiology of the joint disease in HA patients could be analyzed in three different sub-headings; synovium, cartilage and bone problems.

\section{Synovium}

The synovial tissue is the main cleaner of the joint cavity from the blood remnants especially erythrocyte derived iron. The synovium contains fibroblast like synoviocytes (FLSs). FLSs provide extracellular matrix and produce most of the constituents of the synovial fluid (9). In severe and recurrent cases of hemarthroses, the capacity of the synovium to carry the iron outside the joint is overwhelmed. The iron, accumulated in the synovial tissue in the form of hemosiderin, causes some pathological changes in this tissue like inflammation, hyperplasia and angiogenesis $(10,11)$. The increased deposition of iron in the synovial tissues can also exaggerate the production of some cytokines like tumor necrosis factor (TNF)- $\alpha$, interferon-c, interleukin (IL)-1 and IL-6 and can directly induce receptor activator of nuclear factor- $\kappa \mathrm{B}$ ligand (RANKL) to promote synovial hypertrophy (12). Synovial hypertrophy and thickening are the major pathological changes seen in HA patients and caused primarily by increased fibroblast proliferation and expression of some disrupted oncogenes. The oncogenes c-myc and $\mathrm{mdm} 2$ are highly present in the
HA patients' synovium $(13,14)$. The expression of oncogenes is thought to be related to the production of excessive amount of FLSs, monocyte infiltration and cell cycle arrest through the inhibition of direct apoptosis in patients with arthritis $(15,16)$. These changes start a vicious cycle of repeated bleeding and chronic synovitis.

\section{Cartilage}

Cartilage degeneration mechanism in HA patients is complex and generally results from synovitis, bleeding into the joint and also mechanical stresses. The joint damage has both inflammatory and degenerative characters like in rheumatoid arthritis and osteoarthritis respectively (17). Production of some inflammatory cytokines like IL-1, IL- 6 and TNF- $\alpha$ and proteases by synovial tissue causes degradation of cartilage (18). Also these mediators exacerbate synovial hypertrophy and neovascularization after recurrent bleeding into the joint (19). In addition to the cartilage damage caused by the synovitis via indirect ways, presence of the blood in the joint space itself causes direct damage to the cartilage. This explains the severity of the cartilage destruction in HA patients is more than in the inflammatory and degenerative arthritis patients. In an experimental study by Jansen et al. (20), synovial inflammation and apoptosis were shown even after only one bleed into a joint. Cartilage damage caused by synovial production of pro-inflammatory cytokines can be reversible after a single bleed because the chondrocytes could remain viable; but the blood causes extracellular matrix degradation and chondrocyte apoptosis by direct effect resulting irreversible damage (21). Destruction of the cartilage is directly related to the exposure time and blood concentration in the joint (22).

\section{Bone}

Patients with HA have some degree of systemic osteoporosis and local bone loss. Systemic osteoporosis is associated with short stature, lower body weight, decreased activity levels and some infectious diseases like hepatitis $\mathrm{C}$ and HIV (23). Local bone changes around the joints include cyst formation, subchondral sclerosis, osteophyte formation and epiphyseal enlargement (24). Cartilage degeneration could be the primary cause of bone loss in HA patients but the exact mechanism of bone changes are not well known. Even a single bleed might induce the bone loss and this loss can be exaggerated by inactivity, muscle weakness and recurrent bleeding (11). The RANKL/osteoprotegerin pathway plays an important role in regulation of bone turnover. This pathway induces osteoclast differentiation and maturation finally causing bone resorption. As in patients with osteoarthritis, HA patients also have a higher incidence of RANKL overexpression in the affected joints (25). In addition, pro-inflammatory cytokines such as IL-1, IL-6 and TNF- $\alpha$ released in response to the synovitis, could increase the expression of the RANKL in HA patients (26). Subchondral bone cysts are the other prominent features of HA but the mechanism of its occurrence is not fully understood (27).

\section{IMAGING}

\section{Plain Radiography}

The plain radiography has been used successfully in evaluating the HA. It can show arthropathic changes like osteonecrosis, subchondral cysts, joint space narrowing 
and angular problems (Figure 1). The Pettersson score for staging the HA using plain radiography is accepted in 1981 by the World Federation of Hemophilia (28). Each abnormality is graded from 0 to 2 in this scoring system and the highest score could be 13 (Table 1).

While the plain radiography is used in staging the disease, it cannot evaluate the early period of the joint involvement. For this reason, ultrasound (US) and magnetic resonance imaging (MRI) have been advocated for the studying of cartilage damage and early changes of HA.

\section{Ultrasound}

The joint damage and bleeding into the joint could be detected by US in patients with HA (29). It can show osteophytes, chondral defects and synovitis. With the help of Power Doppler US, hyperemia of the synovium caused by hypervascularity in asymptomatic patients might be

Table 1. The Pettersson scoring system for hemophilic arthropathy grading by plain radiography

\begin{tabular}{|c|c|}
\hline Radiographic finding & Score \\
\hline \multicolumn{2}{|l|}{ Osteoporosis } \\
\hline Absent & 0 \\
\hline Present & 1 \\
\hline \multicolumn{2}{|l|}{ Enlarged epiphysis } \\
\hline Absent & 0 \\
\hline Present & 1 \\
\hline \multicolumn{2}{|c|}{ Irregular subchondral surface } \\
\hline Absent & 0 \\
\hline Partially involved & 1 \\
\hline Totally involved & 2 \\
\hline \multicolumn{2}{|l|}{ Narrowing joint space } \\
\hline Absent & 0 \\
\hline$>1 \mathrm{~mm}$ & 1 \\
\hline$<1 \mathrm{~mm}$ & 2 \\
\hline \multicolumn{2}{|c|}{ Subchondral cyst formation } \\
\hline Absent & 0 \\
\hline 1 cyst & 1 \\
\hline$>1$ cyst & 2 \\
\hline \multicolumn{2}{|l|}{ Erosion of joint margins } \\
\hline Absent & 0 \\
\hline Present & 1 \\
\hline \multicolumn{2}{|c|}{ Gross incongruence of articulating bone ends } \\
\hline Absent & 0 \\
\hline Slight & 1 \\
\hline Pronounced & 2 \\
\hline \multicolumn{2}{|c|}{ Joint deformity (angulation, displacement, or both) } \\
\hline Absent & 0 \\
\hline Slight & 1 \\
\hline Pronounced & 2 \\
\hline
\end{tabular}

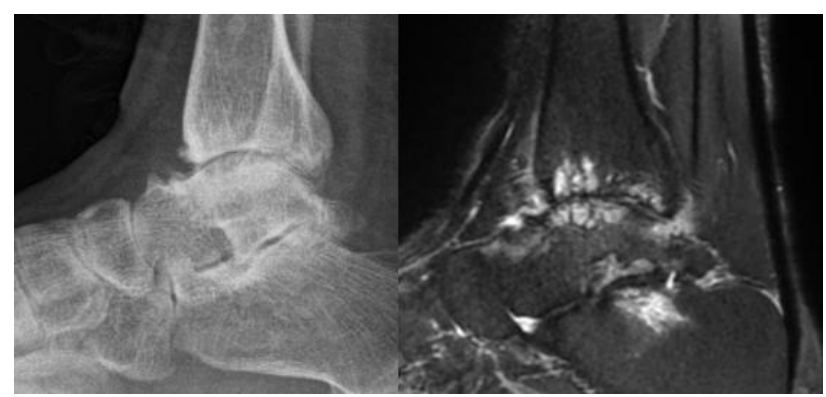

Figure 1. A 23-year-old female patient with an advanced ankle arthopathy secondary to hemophilia diagnosed in early periods and this can help to prevent the progression of the joint damages (30). Also Doppler could differentiate the normal synovial flow and synovitis. But the Doppler imaging has some difficulties in detecting the severity of the bleeding in the joint, and accepted to be a key tool to predict the risk of hemorrhage rather than the active disease (31). Despite its limited ability for comprehensive evaluation of some details about cartilage defects, synovial changes and subchondral bone; it still maintains its value especially in children because it does not require sedation, can examine many joints in a single session and does not require special positioning.

\section{Magnetic Resonance Imaging}

Early detection of effusion in joints, synovitis, bony edema and cartilage involvement can be evaluated by MRI easily. MRI is also sensitive for the visualization of hemosiderin deposits in joints (32). In a prospective study to determine the relationship of MRI findings with joint functions, MRI revealed chondral and synovial abnormalities in $30 \%$ of Pettersson grade 0 patients (33). In this study, presence of hemosiderin was found to be related with the time elapsed between last bleeding and MRI evaluation; recent bled joints were showing significant hemosiderin deposits. But the clinical implications of finding abnormalities in MRI but not in Pettersson scoring system remain unclear. Although MRI is superior to US in evaluating the joint surfaces, the examination time is longer, only one joint can be evaluated at a session and sedation may be required with MRI. US should be the primary choice of screening method especially in patients with multi joint involvement and patients requiring repeated follow-up examinations (24).

\section{MANAGEMENT \\ Prophylaxis}

Prophylaxis has been demonstrated as a standard choice of management to prevent HA development. Primary prophylaxis starting at early years of age is very important to prevent hemorrhages but secondary prophylaxis in adolescents has also significant success rates (34). In a prospective large cohort study by Manco-Johnson et al. (35), the patients with severe hemophilia A taking regular infusions of recombinant factor VIII (prophylaxis) had les joint damage and decreased frequency of hemarthrosis than patients taking factor VIII at the time of bleeding periods (enhanced episodic treatment). Because the high cost of recombinant factor VIII is a significant barrier to be a standard care of prophylaxis worldwide, early detection and monitoring of the joint pathology after the bleeding and just before the joint damage had start is very important.

\section{Joint Aspiration}

As the duration of exposure to the blood increases, degeneration of the cartilage matrix and resultant cartilage loss also increase (36). If the blood in joint cavity is not evacuated at an early period of time, proteoglycan synthesis will be impaired and the chondrocyte apoptosis starts. Aspiration of the joints in patients with higher degree of arthropathy is not indicated because of the benefits thought to be taken by this method is very limited. Today, the mostly accepted modality of management for the acute hemarthrosis in hemophilic patients includes; early factor replacement if possible, joint aspiration, splinting of the extremity to reduce the recurrent bleedings, 
ice applications and cyclooxygenase- 2 inhibitors to relieve pain in selected cases $(37,38)$.

\section{Synovectomy}

After the several trials of injections and other conservative measures fail to solve the bleeding episodes and progressing arthropathy in hemophilic patients, synovectomy should be considered (39). The purpose of synovectomy either with medical or surgical methods is to remove the problematic synovium to prevent the progression of HA. Medical synovectomy (synoviorthesis) has two basic types; radiosynovectomy and chemical synovectomy. Mostly intra-articular injections of rifampicin and oxytetracycline chloride are used for chemical synovectomy. Intra-articular injections of radionuclides 90Y (yttrium-90) (knees) and 186Rh (rhenium-186) (elbows and ankles) are used commonly for radiosynovectomy (40). Radiosynovectomy appears to be more effective than chemical synovectomy with an about $85 \%$ success rates. The safety of these radionuclide agents has been proven by more than 40 years of experience with no reported damaging effects (37). Synoviorthesis should be performed as early as possible to inhibit the chondral damage. Some patients do not need repetitive synovectomy and these patients can continue their lives without bleeding for years. However, in some cases, arthroscopic or open synovectomy should be considered in patients who do not benefit from medical synovectomy repeated 3 times consecutively (41). Arthroscopic synovectomy provides approximately $95 \%$ reduction in hemarthrosis attacks (42). But this procedure needs prolonged factor replacement and postoperative physiotherapy. Especially in children, if possible radiosynovectomy should be the primary choice of synovectomy methods.

\section{Orthopaedic Procedures}

Prophylaxis with appropriate factor replacement, joint aspiration with or without steroid injections and radiosynovectomy are the primary care of the children with HA. If all these measures fail to protect the joint from damaging effects of bleeding, arthroscopic synovectomy might be considered with handling its difficulties. More advanced orthopedic procedures should be taken into consideration after all strategies are insufficient in HA management (43). Arthrodesis can be applied to the patients with severe ankle and elbow arthropathies. In knee and hip joints, arthroplasty option can be considered as a last choice after the age of 18 because of its high complication rates (44). Care should be taken after blunt injury to the quadriceps or gluteal region. Hematoma may shift into compartment syndrome and finally contracture in the long term if it does not managed well. In young adult ages these patients need joint replacement and most common challenging part of the surgery is handling with contractures and deformity.

\section{CONCLUSION}

The mechanism of the joint degeneration in hemophilia patients is complex and not fully understood but the key factor triggering the pathological processes is bleeding into the joint. The joint enters a vicious circle of damage due to the hemorrhage and synovitis, this result in progression into severe arthritis, so the early diagnosis and treatment of this hemorrhage is crucial. US helps in early diagnosis and is a good choice of screening tool for multiple joint involvement and MRI plays an important role in detailed assessment of the joint. Prophylaxis with factor replacement, aspiration of the hematoma and synovectomy are the management options of HA. After the onset of the severe arthropathy, there are little amount of treatment modalities in children like arthrodesis or arthroplasty.

Ethics Committee Approval: Since our study was a review, ethics committee approval was not required.

Conflict of Interest: None declared by the authors.

Financial Disclosure: None declared by the authors.

Acknowledgements: None declared by the authors.

Author Contributions: Idea/Concept: BT, YT; Design: BT, YT; Data Collection/Processing: BT, YT; Analysis/Interpretation: BT, YT; Literature Review: BT, YT; Drafting/Writing: BT, YT; Critical Review: BT, YT.

Editor in Chief's Note: Yalçın Turhan is the Deputy Editor of Duzce Medical Journal, however he did not take place at any stage on the decision of this article.

\section{REFERENCES}

1. Biggs R, Douglas AS, Macfarlane RG, Dacie JV, Pitney WR, Merskey H. Christmas disease: a condition previously mistaken for haemophilia. $\mathrm{Br}$ Med $\mathrm{J}$. 1952;2(4799):1378-82.

2. White GC, Rosendaal F, Aledort LM, Lusher JM, Rothschild C, Ingerslev J. Factor VIII and Factor IX Subcommittee. Definitions in hemophilia. Recommendation of the scientific subcommittee on factor VIII and factor IX of the scientific and standardization committee of the International Society on Thrombosis and Haemostasis. Thromb Haemost. 2001;85(3):560.

3. Srivastava A, Brewer AK, Mauser-Bunschoten EP, Key NS, Kitchen S, Llinas A, et al. Treatment Guidelines Working Group on Behalf of The World Federation Of Hemophilia. Guidelines for the management of hemophilia. Haemophilia. 2013;19(1):e1-47.

4. Bertamino M, Riccardi F, Banov L, Svahn J, Molinari AC. Hemophilia care in the pediatric age. J Clin Med. 2017;6(5):54.

5. Rodriguez-Merchan EC. Articular bleeding in hemophilia. Cardiovasc Hematol Disord Drug Targets. 2016;16(1):21-4.

6. van Vulpen LF, van Meegeren ME, Roosendaal G, Jansen NW, van Laar JM, Schutgens RE, et al. Biochemical markers of joint tissue damage increase shortly after a joint bleed; an explorative human and canine in vivo study. Osteoarthritis Cartilage. 2015;23(1):63-9.

7. Manco-Johnson MJ, Soucie JM, Gill JC. Prophylaxis usage, bleeding rates, and joint outcomes of hemophilia, 1999 to 2010: a surveillance project. Blood. 2017;129(17):2368-74. 
8. Nieuwenhuizen L, Roosendaal G, Coeleveld K, Lubberts E, Biesma DH, Lafeber FP, et al. Haemarthrosis stimulates the synovial fibrinolytic system in haemophilic mice. Thromb Haemost. 2013;110(1):173-83.

9. Bhattaram P, Chandrasekharan U. The joint synovium: A critical determinant of articular cartilage fate in inflammatory joint diseases. Semin Cell Dev Biol. 2017;62:86-93.

10. Nieuwenhuizen L, Schutgens RE, van Asbeck BS, Wenting MJ, van Veghel $\mathrm{K}$, Roosendaal $\mathrm{G}$, et al. Identification and expression of iron regulators in human synovium: evidence for upregulation in haemophilic arthropathy compared to rheumatoid arthritis, osteoarthritis, and healthy controls. Haemophilia. 2013;19(4):e218-27.

11. Bhat V, Olmer M, Joshi S, Durden DL, Cramer TJ, Barnes RF, et al. Vascular remodeling underlies rebleeding in hemophilic arthropathy. Am J Hematol. 2015;90(11):1027-35.

12. Hashizume M, Hayakawa N, Mihara M. IL-6 transsignalling directly induces RANKL on fibroblast-like synovial cells and is involved in RANKL induction by TNF-alpha and IL-17. Rheumatology (Oxford). 2008;47(11):1635-40.

13. Wen FQ, Jabbar AA, Chen YX, Kazarian T, Patel DA, Valentino LA. c-myc proto-oncogene expression in hemophilic synovitis: in vitro studies of the effects of iron and ceramide. Blood. 2002;100(3):912-6.

14. Hakobyan N, Kazarian T, Jabbar AA, Jabbar KJ, Valentino LA. Pathobiology of hemophilic synovitis I: overexpression of mdm2 oncogene. Blood. 2004;104(7):2060-4.

15. Roivainen A, Söderström KO, Pirilä L, Aro H, Kortekangas P, Merilahti-Palo R, et al. Oncoprotein expression in human synovial tissue: an immunohistochemical study of different types of arthritis. Br J Rheumatol. 1996;35(10):933-42.

16. Bartok B, Firestein GS. Fibroblast-like synoviocytes: key effector cells in rheumatoid arthritis. Immunol Rev. 2010;233(1):233-55.

17. Jansen NW, Roosendaal G, Lafeber FP. Understanding haemophilic arthropathy: an exploration of current open issues. Br J Haematol. 2008;143(5):632-40.

18. Srivastava A. Inflammation is key to hemophilic arthropathy. Blood. 2015;126(19):2175-6.

19. Acharya SS, Kaplan RN, Macdonald D, Fabiyi OT, DiMichele D, Lyden D. Neoangiogenesis contributes to the development of hemophilic synovitis. Blood. 2011;117(8):2484-93.

20. Jansen NW, Roosendaal G, Wenting MJ, Bijlsma JW, Theobald M, Hazewinkel HA, et al. Very rapid clearance after a joint bleed in the canine knee cannot prevent adverse effects on cartilage and synovial tissue. Osteoarthritis Cartilage. 2009;17(4):433-40.

21. Hooiveld MJ, Roosendaal G, van den Berg HM, Bijlsma JW, Lafeber FP. Haemoglobin-derived irondependent hydroxyl radical formation in bloodinduced joint damage: an in vitro study. Rheumatology (Oxford). 2003;42(6):784-90.

22. Zhu H, Meng Y, Tong P, Zhang S. Pathological mechanism of joint destruction in haemophilic arthropathy. Mol Biol Rep. 2021;48(1):969-974.
23. Kovacs CS. Hemophilia, low bone mass, and osteopenia/osteoporosis. Transfus Apher Sci. 2008;38(1):33-40.

24. van Vulpen LFD, Holstein K, Martinoli C. Joint disease in haemophilia: Pathophysiology, pain and imaging. Haemophilia. 2018;24(Suppl 6):44-9.

25. Christensen KR, Kjelgaard-Hansen M, Nielsen LN, Wiinberg B, Alexander Althoehn F, Bloksgaard Poulsen N, et al. Rapid inflammation and early degeneration of bone and cartilage revealed in a timecourse study of induced haemarthrosis in haemophilic rats. Rheumatology (Oxford). 2019;58(4):588-99.

26. Christoforidis A, Economou M, Papadopoulou E, Kazantzidou E, Farmaki E, Tzimouli V, et al. Comparative study of dual energy X-ray absorptiometry and quantitative ultrasonography with the use of biochemical markers of bone turnover in boys with haemophilia. Haemophilia. 2011;17(1):e217-22.

27. Christensen KR, Roepstorff K, Petersen M, Wiinberg B, Hansen AK, Kjelgaard-Hansen M, Nielsen LN. Visualization of haemophilic arthropathy in F8-/- rats by ultrasonography and micro-computed tomography. Haemophilia. 2017;23(1):152-62.

28. Pettersson H, Ahlberg A, Nilsson IM. A radiologic classification of hemophilic arthropathy. Clin Orthop Relat Res. 1980;(149):153-9.

29. Melchiorre D, Linari S, Innocenti M, Biscoglio I, Toigo M, Cerinic MM, et al. Ultrasound detects joint damage and bleeding in haemophilic arthropathy: a proposal of a score. Haemophilia. 2011;17(1):112-7.

30. Kidder W, Nguyen S, Larios J, Bergstrom J, Ceponis A, von Drygalski A. Point-of-care musculoskeletal ultrasound is critical for the diagnosis of hemarthroses, inflammation and soft tissue abnormalities in adult patients with painful haemophilic arthropathy. Haemophilia. 2015;21(4):530-7.

31. Di Minno MN, Ambrosino P, Quintavalle G, Coppola A, Tagliaferri A, Martinoli C, et al. Assessment of hemophilic arthropathy by ultrasound: Where do we stand? Semin Thromb Hemost. 2016;42(5):541-9.

32. Majeed H, Ahmed H, Sussman MS, Macgowan C, Rayner T, Weiss R, et al. Understanding early hemophilic arthropathy in children and adolescents through MRI T2 mapping. J Magn Reson Imaging. 2021;53(3):827-37.

33. Den Uijl IE, De Schepper AM, Camerlinck M, Grobbee DE, Fischer K. Magnetic resonance imaging in teenagers and young adults with limited haemophilic arthropathy: baseline results from a prospective study. Haemophilia. 2011;17(6):926-30.

34. Ar MC, Baslar Z, Soysal T. Personalized prophylaxis in people with hemophilia A: challenges and achievements. Expert Rev Hematol. 2016;9(12):1203-8.

35. Manco-Johnson MJ, Abshire TC, Shapiro AD, Riske B, Hacker MR, Kilcoyne R, et al. Prophylaxis versus episodic treatment to prevent joint disease in boys with severe hemophilia. N Engl J Med. 2007;357(6):535-44.

36. Jansen NW, Roosendaal G, Bijlsma JW, Degroot J, Lafeber FP. Exposure of human cartilage tissue to low concentrations of blood for a short period of time leads to prolonged cartilage damage: an in vitro study. Arthritis Rheum. 2007;56(1):199-207. 
37. Nacca CR, Harris AP, Tuttle JR. Hemophilic arthropathy. Orthopedics. 2017;40(6):e940-6.

38. Tat NM, Tat AM, Oner AF, Karaman K, Kaplan S, Can F. Static postural balance evaluation and an investigation of the relationship with joint health in children with severe haemophilia: a controlled crosssectional study. Haemophilia. 2021;27(2):e245-52.

39. Raffini L, Manno C. Modern management of haemophilic arthropathy. $\mathrm{Br} \mathrm{J}$ Haematol. 2007;136(6):777-87.

40. Rodriguez-Merchan EC, Quintana M, De la CorteRodriguez H, Coya J. Radioactive synoviorthesis for the treatment of haemophilic synovitis. Haemophilia. 2007;13(Suppl 3):32-7.
41. Acharya SS. Hemophilic joint disease - current perspective and potential future strategies. Transfus Apher Sci. 2008;38(1):49-55.

42. Dunn AL, Busch MT, Wyly JB, Sullivan KM, Abshire TC. Arthroscopic synovectomy for hemophilic joint disease in a pediatric population. J Pediatr Orthop. 2004;24(4):414-26.

43. Acharya SS. Exploration of the pathogenesis of haemophilic joint arthropathy: understanding implications for optimal clinical management. $\mathrm{Br} \mathbf{J}$ Haematol. 2012;156(1):13-23.

44. Ingerslev J, Hvid I. Surgery in hemophilia. The general view: patient selection, timing, and preoperative assessment. Semin Hematol. 2006;43(Suppl 1):S23-6. 